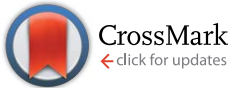

Cite this: RSC Adv., 2015, 5, 102750

Received 7th October 2015

Accepted 16th November 2015

DOI: $10.1039 / \mathrm{c} 5 \mathrm{ra} 20739 \mathrm{~h}$

www.rsc.org/advances

\section{Evaluation of contact time and fiber morphology on bacterial immobilization for development of novel surfactant degrading nanofibrous webs $\uparrow$}

\begin{abstract}
Omer Faruk Sarioglu, ${ }^{a}$ Asli Celebioglu, ${ }^{b}$ Turgay Tekinay ${ }^{\star c d}$ and Tamer Uyar ${ }^{\star a b}$
Novel electrospun fibrous biocomposites were developed by immobilizing two different sodium dodecyl sulfate (SDS) biodegrading bacterial strains, Serratia proteamaculans STB3 and Achromobacter xylosoxidans STB4 on electrospun non-porous cellulose acetate (nCA) and porous cellulose acetate $(\mathrm{pCA})$ webs. The required contact time for bacterial immobilization was determined by SEM imaging and viable cell counting of the immobilized bacteria, and bacterial attachment was ended at day 25 based on these results. SDS biodegradation capabilities of bacteria immobilized webs were evaluated at different concentrations of SDS, and found to be highly efficient at concentrations up to $100 \mathrm{mg} \mathrm{L}^{-1}$. It was observed that SDS remediation capabilities of bacteria immobilized webs were primarily based on the bacterial existence and very similar to the free-bacterial cells. A reusability test was applied on the two most efficient webs (STB3/pCA and STB4/pCA) at $100 \mathrm{mg} \mathrm{L}^{-1}$ SDS, and the results suggest that the webs are potentially reusable and improvable for SDS remediation in water. SEM images of bacteria immobilized webs after the reusability test demonstrate strong bacterial adhesion onto the fibrous surfaces, which was also supported by the viable cell counting results. Our results are highly promising and suggest that bacteria immobilized electrospun fibrous webs have the potential to be used effectively and continually for remediation of SDS from aqueous environments.
\end{abstract}

\section{Introduction}

Surface active agents (surfactants) are the major components of detergents and are commonly used in various industrial and domestic applications, leading to a significant contribution to water pollution. ${ }^{1}$ According to the United States Environmental Protection Agency (USEPA), surfactants may negatively influence the endocrine system of both animals and humans, so constituting a considerable health hazard. ${ }^{2}$ Therefore, decontamination of water sources from surfactants is of substantial importance.

There are different methods to treat surfactant contaminated environments and bioremediation is becoming an emerging technology for decontamination of these pollutants,

${ }^{a}$ Institute of Materials Science \& Nanotechnology, Bilkent University, 06800, Bilkent, Ankara, Turkey. E-mail: uyar@unam.bilkent.edu.tr; Fax: +90312266 4365; Tel: +90 3122908987

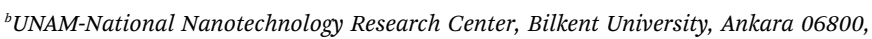
Turkey

${ }^{c}$ Gazi University, Department of Medical Biology and Genetics, Faculty of Medicine, 06500, Besevler, Ankara, Turkey. E-mail: ttekinay@gazi.edu.tr; Fax: +90 312484 6271; Tel: +903124846270

${ }^{d}$ Gazi University, Life Sciences Application and Research Center, 06830, Golbasi, Ankara, Turkey

$\dagger$ Electronic supplementary information (ESI) available. See DOI: $10.1039 / \mathrm{c} 5 \mathrm{ra} 20739 \mathrm{~h}$ since it is cost-effective, eco-friendly and effective for a wide variety of pollutants such as petroleum hydrocarbons, heavy metals and surfactants. ${ }^{3}$ Although there are numerous reports in the literature about the isolation and discovery of novel surfactant degrading microorganisms, their in situ application is not so simple, since the environmental parameters are highly variable and the rate of surfactant degradation is very low under natural conditions. ${ }^{4}$ Therefore, alternative application procedures should be studied and the degradation conditions should be optimized for specific microorganisms to obtain better remediation performance under variable physical and environmental conditions.

The genus Achromobacter comprises Gram-negative, aerobic, non-fermenting and rod-shaped bacteria. ${ }^{5}$ It has been reported that Achromobacter xylosoxidans has petroleum hydrocarbon degrading capability and is able to grow in crude oil contaminated environments, ${ }^{6}$ which may indicate the potential surfactant degrading capability of this species, since large amounts of industrial surfactants are derived from petroleum. The genus Serratia is a member of the Enterobacteriaceae, and comprises Gram-negative, non-spore forming, glucose fermenting, facultatively anaerobic and rod-shaped bacteria. ${ }^{7,8}$ Serratia odorifera, a member of the genus Serratia, has shown efficient surfactant degrading capability in consortia against two different common surfactants, LAS and SLES, ${ }^{\mathbf{9}, 10}$ highlighting the potential of this family for application to surfactant bioremediation. 
Bioremediation techniques can be applied with either free microorganisms or immobilized microorganisms which are adhered on a carrier matrix. Application of immobilized microorganisms is more advantageous than the freely floating cells in terms of lower space and growth medium requirements and potential reusability of the system. ${ }^{11}$ Furthermore, it is also advantageous for the resistance of cells to harsh environmental extremes. ${ }^{12}$ As a carrier material, electrospun fibrous webs have become a promising candidate since electrospinning is a simple, versatile and cost-effective technique and electrospun fibrous webs can have unique properties such as large surfaceto-volume ratio and high porosity, hence these materials have the potential to be used in membrane/filter applications. ${ }^{\mathbf{1 3 - 1 8}}$ Among different immobilization procedures, natural adhesion is the most advantageous one since it provides the formation of biofilms, maximizes the cell viability and biochemical activity. ${ }^{19}$ In recent years, few studies regarding environmental applications of microorganism immobilized electrospun fibrous webs have been published. ${ }^{\mathbf{1 1 , 2 0 - 2 4}}$

In the current study, Serratia proteamaculans STB3 and Achromobacter xylosoxidans STB4 cells, which have biodegradation capabilities on a known anionic surfactant: sodium dodecyl sulfate (SDS), were immobilized onto cellulose acetate nanofibers that have either non-porous or porous morphology to obtain reusable materials for surfactant remediation in aqueous systems. We describe here the development procedure of bacteria immobilized biocomposites and their potential reusability. Our reusability test results indicate that the biocomposites have a potential to be reused for continuous remediation of surfactants in water.

\section{Experimental}

\subsection{Materials}

Dichloromethane (DCM, $\geq 99 \%$ (GC), Sigma-Aldrich), acetone ( $\geq 99 \%$ (GC), Sigma-Aldrich), methanol (99.7\%, Riedel), cellulose acetate, (CA, $M_{\mathrm{w}}$ : $30000 \mathrm{~g} \mathrm{~mol}^{-1}, 39.8 \mathrm{wt} \%$ acetyl, SigmaAldrich), sodium dodecyl sulfate (SDS, $\geq 98.5 \%$ (GC), SigmaAldrich), methylene blue ( $\geq 82 \%$, Sigma-Aldrich), nutrient broth (Sigma-Aldrich), LB broth (Sigma-Aldrich) and agar (Sigma-Aldrich) were purchased and used without any purification.

\subsection{Electrospinning of non-porous and porous cellulose acetate webs}

Porous cellulose acetate (pCA) and non-porous cellulose acetate (nCA) nanofibers were produced by using different binary solvent systems. For pCA nanofibers, the procedure was determined from our previous study. ${ }^{25}$ The homogenous electrospinning solutions were prepared by dissolving CA in DCM/ methanol $(4 / 1(\mathrm{v} / \mathrm{v}))$ and DCM/acetone (1/1 (v/v)) solvent mixtures at $12 \%(\mathrm{w} / \mathrm{v})$ and $10 \%(\mathrm{w} / \mathrm{v})$ polymer concentrations for nCA and pCA nanofibers, respectively. Afterwards, these clear solutions were loaded in a $3 \mathrm{~mL}$ syringe fitted with a metallic needle of $0.4 \mathrm{~mm}$ inner diameter and they were located horizontally on a syringe pump (model KDS-101, KD Scientific,
USA). One of the electrodes of a high-voltage power supply (Spellman, SL30, USA) was clamped to the metallic needle and the plate aluminum collector was grounded. Electrospinning parameters were arranged as follows: feed rate of solutions = $0.5 \mathrm{~mL} \mathrm{~h}^{-1}$, applied voltage $=10-15 \mathrm{kV}$, tip-to-collector distance $=10-12 \mathrm{~cm}$. The grounded stationary metal collector covered with an aluminum foil was used to deposit the electrospun nCA and pCA nanofibers. The electrospinning apparatus was enclosed in a Plexiglas box and electrospinning was carried out at about $23{ }^{\circ} \mathrm{C}$ at $20 \%$ relative humidity. The collected nanofibers/nanowebs were dried overnight at room temperature in a fume hood.

\subsection{Isolation, preliminary characterization and $16 S$ rRNA gene sequence analysis of STB3 and STB4 strains}

The aim was to find and isolate specific and efficient bacterial strains for surfactant remediation and therefore, different water samples were collected from the area nearby a wastewater effluent (which contain low amounts of anionic surfactants) of a glassware producing factory (Trakya Glass Bulgaria EAD). The bacterial isolates were then enriched in LB medium (LuriaBertani: $10 \mathrm{~g} \mathrm{~L}^{-1}$ tryptone, $5 \mathrm{~g} \mathrm{~L}^{-1}$ yeast extract, $10 \mathrm{~g} \mathrm{~L}^{-1} \mathrm{NaCl}$ in $1 \mathrm{~L}$ of distilled water) and plated on LB-agar plates to obtain pure cultures. All reagents utilized in this study were purchased from Sigma-Aldrich (USA). The pure cultures were collected from the plates, enriched in LB medium, named with the designation "STB" and their preliminary characterization for surfactant remediation was performed with lower amounts of (5-10 $\mathrm{mg} \mathrm{L}^{-1}$ ) SDS containing LB growth media. The remaining concentrations of SDS in the culture media were measured by MBAS (methylene blue active substances) assay in each biodegradation experiment, in which methylene blue binds with anionic surfactants in an aqueous medium and the mixture gives an absorbance peak at $652 \mathrm{~nm} .{ }^{26}$ The most efficient bacterial isolates for SDS remediation were selected as STB3 and STB4 strains.

The species identity of STB3 and STB4 were determined via 16S rRNA gene sequencing analysis. Bacterial DNA isolation was carried out using a DNeasy Blood \& Tissue Kit (QIAGEN, Germany). A modified protocol for PCR amplification and further sequencing was utilized with concentrations of: $1.25 \mathrm{U}$ Platinum Taq polymerase, $0.2 \mathrm{mM}$ dNTP, 0.4 pmol $\mathrm{T} 3$ (ATTAACCCTCACTAAAGGGA) and T7 (TAATACGACTCACTATAGGG) primers which encompass the entire 16S gene, $1.5 \mathrm{mM}$ $\mathrm{MgCl}$ and $1 \mathrm{X}$ Taq buffer. ${ }^{27}$ The PCR steps were adjusted as: initial denaturation at $96^{\circ} \mathrm{C}$ for $5 \mathrm{~min}$ and a further 30 cycles of denaturation at $96{ }^{\circ} \mathrm{C}$ for $30 \mathrm{~s}$, annealing at $55{ }^{\circ} \mathrm{C}$ for $30 \mathrm{~s}$, elongation at $72{ }^{\circ} \mathrm{C}$ for $30 \mathrm{~s}$ and a final elongation at $72{ }^{\circ} \mathrm{C}$ for 5 min. The sequencing was done via a 3130xl Genetic Analyzer by using a BigDye Terminator v3.1 Cycle Sequencing Kit (Applied Biosystems, USA), and the analysis was performed with an ABI 3130xl Genetic Analyzer. The 16S rRNA gene sequences of the isolates were analyzed by the NCBI's Bacterial Blast Tool (http:// www.ncbi.nlm.nih.gov) and an online phylogenetic tree printer (Phylohendron, http:/www.iubio.bio.indiana.edu/treeapp/ 
treeprint-form.html) was utilized to construct and visualize the phylogenetic trees.

\subsection{Growth and immobilization of STB3 and STB4 cells}

Immobilization of STB3 and STB4 cells was provided by the inclusion of cellulose acetate nanofibrous webs (which have either porous (pCA) or non-porous (nCA) morphology) into the growth media of newly inoculated bacteria. The procedure including electrospinning and bacterial immobilization is represented in Fig. 1 schematically. Nutrient broth $\left(1 \mathrm{~g} \mathrm{~L}^{-1}\right.$ meat extract, $2 \mathrm{~g} \mathrm{~L}^{-1}$ yeast extract, $5 \mathrm{~g} \mathrm{~L}^{-1}$ peptone, $5 \mathrm{~g} \mathrm{~L}^{-1} \mathrm{NaCl}$ in $1 \mathrm{~L}$ of distilled water) was utilized as the bacterial growth medium. Bacterial growth was maintained in $100 \mathrm{~mL}$ culture flasks for about 25 days at $25{ }^{\circ} \mathrm{C}$ and $180 \mathrm{rpm}$, and the growth media were refreshed for every 7 days. For the evaluation of bacterial attachment, equivalent samples with equal weights (w/v ratio of $0.5 \mathrm{mg} \mathrm{mL}^{-1}$ ) were taken at day 7, 21 and at the end of the reusability test; and the bacterial quantity was determined via a modified protocol in which the immobilized bacterial cells were detached via sonication and viable cell counting was applied on the detached cells. ${ }^{28}$ Briefly, the bacteria immobilized web samples were first collected and gently washed via PBS (Phosphate-Buffered Saline) to remove unattached cells. The web samples were then transferred to $1 \mathrm{~mL}$ buffer containing sterile microcentrifuge tubes and vortexed for $30 \mathrm{~s}$ before sonication. Sonication was conducted at $40 \mathrm{kHz}$ and $4{ }^{\circ} \mathrm{C}$ (the sonication bath was pre-cooled and the temperature was kept constant to prevent excess heat generation and subsequent cell viability loss) by using an ultrasonic cleaner (B2510, Branson Ultrasonics, USA). The cycles were adjusted at 1 min sonication and $30 \mathrm{~s}$ rest for each run, till $10 \mathrm{~min}$ of sonication was completed. At the end of sonication, the web samples were vortexed for $30 \mathrm{~s}$ and the detached bacteria containing buffer samples were transferred to new sterile microcentrifuge tubes. The sonication was repeated once again with fresh buffers and the detached cells for each sample were combined in single tubes. A viable cell counting (VCC) assay was applied for detached cells by spreading them on nutrient-agar plates. After overnight incubation, cfu (colony forming unit) values for each sample were determined. Bacterial immobilization was also checked with SEM microscopy, which is detailed in further sections. After deciding 25 days of incubation is enough for both STB3 and STB4 cell attachment, equivalent bacteria immobilized nCA and pCA web samples (with equal w/v ratios) were prepared for SDS biodegradation experiments.

\subsection{SDS biodegradation experiments}

Nutrient broth was utilized as the bacterial growth medium for SDS biodegradation experiments. Samples were collected periodically to analyze remaining SDS concentrations by MBAS assay. In the first experiment, free STB3 and STB4 cells were tested for SDS biodegradation capability at various $\mathrm{pH}$ levels

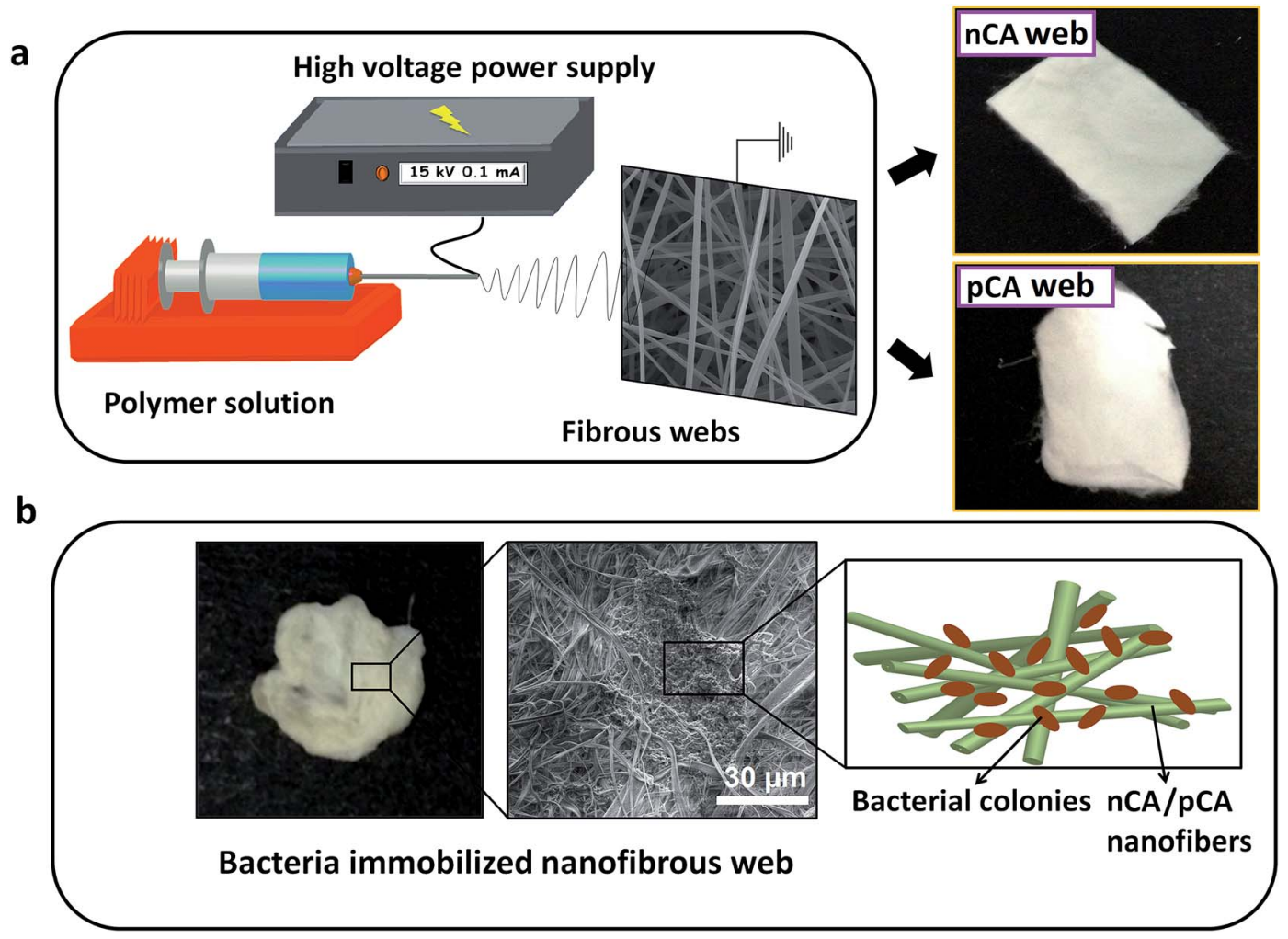

Fig. 1 (a) Schematic representation of the electrospinning process for $\mathrm{nCA}$ and pCA webs, and photographs of nCA and pCA webs, (b) representative images for bacteria immobilized webs including a SEM micrograph and schematic representation of bacterial cells on fibrous surfaces. 
(6.0-8.0). The initial SDS concentration was $10 \mathrm{mg} \mathrm{L}^{-1}$ and the bacterial samples were incubated for $72 \mathrm{~h}$ at $180 \mathrm{rpm}$ and $30^{\circ} \mathrm{C}$. For further experiments, the $\mathrm{pH}$ level was adjusted to 7.0, since it was the optimum level for the STB4 strain which exhibited the highest degradation capacity. In the second and third experiments, pristine nCA and pCA webs, STB3 immobilized nCA and pCA webs, and STB4 immobilized nCA and pCA webs were tested for their SDS remediation capability at 10 and $100 \mathrm{mg} \mathrm{L}^{-1}$ of initial SDS, with the same conditions as for the first experiment. In the fourth experiment, STB3 immobilized pCA webs and STB4 immobilized pCA webs were tested for SDS biodegradation capability at a high concentration $\left(1 \mathrm{~g} \mathrm{~L}^{-1}\right)$ and the samples were incubated for $168 \mathrm{~h}$ at $180 \mathrm{rpm}$ and $30^{\circ} \mathrm{C}$. Only STB3 immobilized pCA webs and STB4 immobilized pCA webs were selected for this experiment since they have shown the highest biodegradation capability among STB3 and STB4 immobilized web samples in the previous experiment. In each experiment, the utilized web samples were washed gently with PBS before the initiation of the experiment. The w/v ratios were equal for each web sample $\left(0.5 \mathrm{mg} \mathrm{mL}^{-1}\right)$. All tests were done in triplicate.

The removal capacities $\left(Q_{\text {eq }}\right)$ of free STB3 and STB4 cells, and bacteria immobilized web samples were calculated by eqn (1)

$$
Q_{\text {eq }}\left(\mathrm{mg} \mathrm{g}^{-1}\right)=\left(C_{0}-C_{\mathrm{f}}\right) \times V / M
$$

where $C_{0}$ is the initial SDS concentration $\left(\mathrm{mg} \mathrm{L}^{-1}\right), C_{\mathrm{f}}$ is the final SDS concentration ( $\left.\mathrm{mg} \mathrm{L}^{-1}\right), V$ is the solution volume (L) and $M$ is the total bacterial cell biomass $(\mathrm{g})$ at equilibrium. ${ }^{29}$

\subsection{Adsorption isotherms and kinetics studies}

Adsorption coefficients of STB3/pCA and STB4/pCA webs were estimated for three isotherm models (Freundlich, Langmuir and Toth) by using the calculated $Q_{\mathrm{eq}}$ and $C_{\mathrm{f}}$ values, that are required for the isotherm parameter fitting software IsoFit $^{30}$ to generate adsorption isotherms, from three different experiments (Fig. 4b-d). The order of reactions for SDS removal were evaluated by plotting zero, first, second and third order plots of STB3/pCA and STB4/pCA webs, and comparing their $R^{2}$ values afterwards.

\subsection{LC-MS (liquid chromatography-mass spectroscopy)}

LC-MS analysis was performed without column separation for the samples; SDS only, nutrient broth only, STB3 postincubation and STB4 post-incubation by using a TOF LC/MS system (6224, Agilent Technologies, USA). The SDS only sample contained $100 \mathrm{mg} \mathrm{\textrm {L } ^ { - 1 }}$ of SDS, while STB3 and STB4 samples contained $100 \mathrm{mg} \mathrm{\textrm {L } ^ { - 1 }}$ of SDS before starting bacterial growth at $72 \mathrm{~h}$ and $30{ }^{\circ} \mathrm{C}$. STB3 and STB4 post-incubation samples were prepared by first collecting the bacterial cultures after the incubation period in sterile centrifuge tubes, centrifuging them at $6000 \mathrm{rpm}$ for $5 \mathrm{~min}$, and then transferring the supernatant portions to HPLC vials to be analyzed with LCMS. The experimental parameters were: ion polarity: negative, LC stream: MS, mass range: $50-3000 \mathrm{~m} / z$, acquisition rate: 1.03 spectra per s, acquisition time: $966.5 \mathrm{~ms}$ per spectrum, flow: 0.5 $\mathrm{mL} \min ^{-1}$, pressure limit: $0-400$ bar.

\subsection{Scanning electron microscopy (SEM)}

Millimeter-length nCA and pCA webs were prepared for SEM analysis to evaluate bacterial attachment. The sample fixation was done by using a modified protocol, similar to that of Greif and colleagues. ${ }^{31}$ Briefly, web samples were washed twice with PBS and then incubated overnight in $2.5 \%$ glutaraldehyde (prepared in PBS) for sample fixation. After overnight incubation, the web samples were washed twice with PBS and a dehydration protocol was applied on those samples by immersion in a series of EtOH solutions (30-96\%). At the end of dehydration, samples were coated with $5 \mathrm{~nm}$ Au-Pd for SEM imaging (Quanta 200 FEG SEM, FEI Instruments, USA).

\subsection{Reusability test}

Reusability of STB3/pCA and STB4/pCA biocomposites was tested for remediation of SDS. Prior to each cycle, the web samples were washed gently with PBS to remove unattached bacteria. The experiments were performed at an initial SDS concentration of $100 \mathrm{mg} \mathrm{L}^{-1}$ with the parameters of: incubation at $180 \mathrm{rpm}$ and $30{ }^{\circ} \mathrm{C}$ for $72 \mathrm{~h}$. SDS concentrations in the media were measured at the beginning and at the end for each run, and the percentile removal of SDS was calculated upon these results. The washing step was repeated for each web sample before starting the next one. All tests were done in triplicate.

\section{Results and discussion}

\subsection{Identification and preliminary characterization of the bacterial isolates}

STB3 and STB4 isolates were collected nearby an industrial effluent which contains low amounts of anionic surfactants, and therefore thought to be a potential candidate for bioremediation of anionic surfactants. According to the preliminary characterization studies, both strains have shown biodegradation capability against SDS at concentrations of $5-10 \mathrm{mg} \mathrm{L}^{-1}$. 16S rRNA gene sequencing analysis was applied on these two strains and the neighbor-joining phylogenetic tree of STB3 and STB4 strains are shown in Fig. S1 in the ESI. $\dagger$ As seen in Fig. S1, $\dagger$ the STB3 strain shows closest identity (95\%) with Serratia proteamaculans and STB4 strain shows closest identity (97\%) with Achromobacter xylosoxidans, hence the isolates were designated as Serratia protemaculans STB3 and Achromobacter xylosoxidans STB4. The strains STB3 and STB4 were deposited in GenBank with the accession numbers of KR094855 and KR094856, and the gene sequences are accessible with those accession numbers.

\subsection{Immobilization of bacterial cells on nCA and pCA webs and evaluation of contact time on bacterial integration}

Depending on the solvent type for the electrospinning solution, CA nanofibers can be obtained in non-porous (nCA) or porous (pCA) morphology. It is known that electrospun CA nanofibers are suitable matrices for biological use, and the high porosity 
along with the higher surface area of pCA nanofibers may have a greater potential to be utilized in biological applications. ${ }^{20}$ The morphologies of nCA and pCA nanofibers are shown in Fig. 2, demonstrating nanoscale pores are present on pCA nanofibers. The fiber diameters of nCA and pCA nanofibers ranged between 0.5 to $3 \mu \mathrm{m}$. A modified protocol ${ }^{27}$ was applied for web samples to quantify the approximate amount of the attached bacteria at different time periods, and SEM imaging was performed to support these results. Fig. S2a and b $\dagger$ show Serratia proteamaculans STB3 cells on nCA and pCA nanofibers after 7 days of incubation, wherein the bacterial attachment was not sufficient. Fig. S2c and $\mathrm{d} \dagger$ show Achromobacter xylosoxidans STB4 cells on nCA and pCA nanofibers, which revealed bacterial cells attached more strongly on nCA nanofibers. Fig. $3 \mathrm{a}$ and $\mathrm{b}$ show Serratia proteamaculans STB3 cells on nCA and pCA nanofibers, while Fig. 3c and d show Achromobacter xylosoxidans STB4 cells on nCA and pCA nanofibers after 21 days of incubation, which all revealed that bacterial attachment was adequate for each sample to initiate biodegradation studies, this was also supported by the viable cell counting results (Table 1). Therefore, at least 21 days was found to be required for both STB3 and STB4 strains, and the web samples were collected after 25 days of incubation. From the viable cell counting results, it was inferred that bacterial cells have difficulty in adhering on nanoporous surfaces since a lower number of bacterial immobilization was achieved for pCA samples at days 7 and 21. A similar behavior was also observed for different kinds of Gram-negative bacteria (Pseudomonas fluorescens and two different strains of Escherichia coli), which showed that bacterial cells attach preferably on nanosmooth silica surfaces rather than patterned, nanoporous surfaces at the mature biofilm stage, and this has been elucidated by the tendency of bacterial cells to maximize their contact area with the substrate surface during immobilization. ${ }^{32}$ Since bacterial attachment came into saturation in the STB4/ nCA sample after 7 days, no significant increase in bacterial number could be observed after 21 days for this sample; nevertheless, the bacterial attachment on the STB4/pCA sample was not saturated after 7 days, hence the bacterial number highly increased and became closer to the STB4/nCA sample's, barely after an adequate time of incubation (21 days). This result implies that, while the nanoporous morphology of pCA webs complicates the bacterial cells' initial colonization, it might not lead to a significant effect on the maximal bacterial
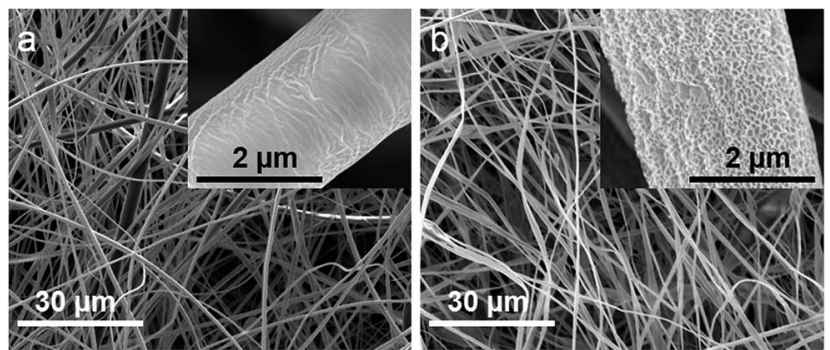

Fig. 2 SEM micrographs of (a) pristine nCA and (b) pristine pCA webs Pores can be seen on a pCA nanofiber in the inset figure.

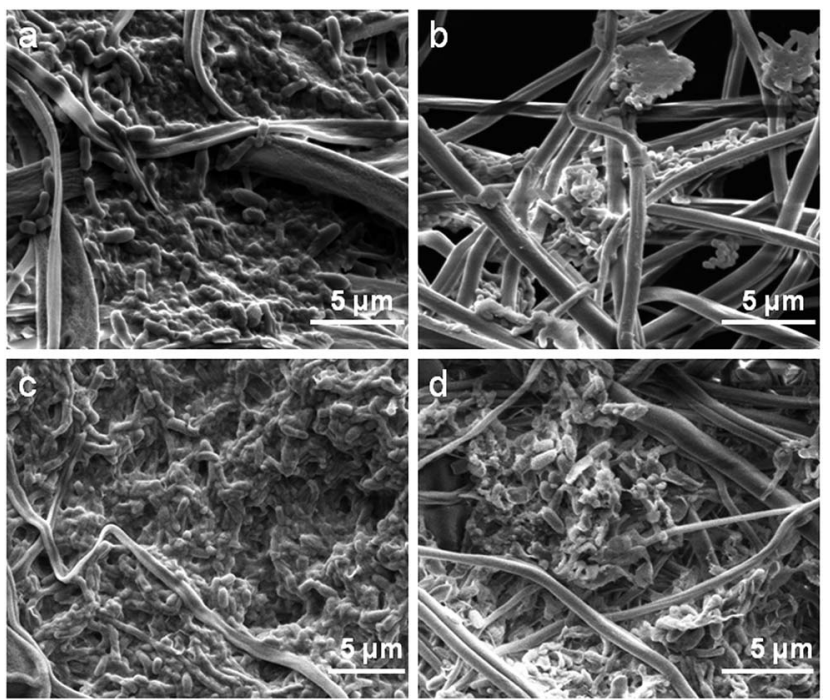

Fig. 3 SEM micrographs of $(a, c) n C A$ and $(b, d)$ pCA nanofibers showing immobilization of STB3 cells onto (a) nCA nanofibers and (b) pCA nanofibers; and immobilization of STB4 cells onto (c) nCA nanofibers and (d) pCA nanofibers after 21 days of incubation.

attachment capacity, since higher numbers of bacterial attachment were obtained on pCA samples latterly.

To summarize, the morphological difference in CA webs was found to be effective for bacterial adhesion and the required contact time. After finishing the bacterial immobilization process at day 25 , the web samples were collected and SDS biodegradation experiments were started with those samples.

\subsection{SDS biodegradation capability of STB3/nCA, STB3/pCA, STB4/nCA and STB4/pCA webs}

Serratia proteamaculans STB3 and Achromobacter xylosoxidans STB4 cells show slight differences in SDS biodegradation profiles at different $\mathrm{pH}$ levels $(6.0-8.0)$ for an initial SDS concentration of $10 \mathrm{mg} \mathrm{L}^{-1}$ (Fig. 4a), suggesting both strains can be utilized efficiently within this $\mathrm{pH}$ range. For further studies, the $\mathrm{pH}$ was adjusted to 7.0, since the best SDS biodegradation profile was obtained by Achromobacter xylosoxidans STB4 cells at this $\mathrm{pH}$ level. In the second experiment (Fig. 4b), STB4/nCA and STB4/pCA biocomposite webs have shown better SDS biodegradation profiles than free STB4 cells and the other webs, STB3/nCA and STB3/pCA biocomposite webs have shown similar SDS biodegradation profiles with free STB3 cells, and pristine nCA and pCA webs have shown only slight decreases in the initial SDS concentration $\left(10 \mathrm{mg} \mathrm{L}^{-1}\right)$ with a relatively larger decrease for pristine pCA webs. This result suggests the biocomposite webs can provide the same remediation performance without adding any additional bacterial inocula to the aqueous system. In the third experiment (Fig. 4c), the same samples were tested at a higher concentration of SDS $\left(100 \mathrm{mg} \mathrm{L}^{-1}\right)$ with the same conditions as for the previous experiment. Interestingly, it was observed that the STB3/pCA web shows the best SDS biodegradation profile among the different samples for the degradation of $100 \mathrm{mg} \mathrm{L}^{-1}$ 
Table 1 Viable cell counting (VCC) results of STB3/nCA, STB3/pCA, STB4/nCA and STB4/pCA webs at different time periods. The results are presented in cfu $\mathrm{mL}^{-1}$. The $\mathrm{w} / \mathrm{v}$ ratio of each web that was utilized for the detachment process was equal $\left(0.5 \mathrm{mg} \mathrm{mL}^{-1}\right)$

\begin{tabular}{|c|c|c|c|c|}
\hline Attachment time & STB3/nCA & STB3/pCA & STB $4 / \mathrm{nCA}$ & STB4/pCA \\
\hline 7 days & $0.3 \times 10^{9} \pm 0.04$ & $0.25 \times 10^{9} \pm 0.04$ & $3.1 \times 10^{9} \pm 1.2$ & $1.4 \times 10^{9} \pm 0.17$ \\
\hline 21 days & $1.15 \times 10^{9} \pm 0.4$ & $0.6 \times 10^{9} \pm 0.11$ & $3.15 \times 10^{9} \pm 0.85$ & $2.65 \times 10^{9} \pm 0.54$ \\
\hline
\end{tabular}

of SDS. STB4/pCA and STB3/nCA samples show very similar SDS biodegradation profiles, while STB4/nCA web shows the lowest SDS biodegradation among the four different biocomposite webs. Similar to the previous experiment, pristine nCA and pCA webs show a slight decreases in the initial SDS concentration, which possibly occurred due to adsorption. In this case, decreases in SDS concentrations for pristine nCA and pCA webs were observed to be very similar, which contradicted our previous thought that pCA webs may have a higher adsorption capability for SDS due to their higher porosity. In the final SDS biodegradation experiment (Fig. 4d), we increased both the initial SDS concentration and incubation time to test the SDS biodegradation capability of our best biocomposite webs (including both bacterial strains) at considerably high concentrations of SDS $\left(1 \mathrm{~g} \mathrm{~L}^{-1}\right)$. Similar to the third experiment, the STB3/pCA web shows a better SDS biodegradation profile (85\%) than STB4/pCA web (63\%) within $168 \mathrm{~h}$, which suggests STB3 cells may have a higher SDS biodegradation capability than
STB4 cells at higher concentrations of SDS. Degradation capacities $\left(Q_{\text {eq }}\right)$ of free cells and biocomposite webs were calculated at $\mathrm{pH} 7.0$ for the concentrations of 10 and $100 \mathrm{mg} \mathrm{L}^{-1}$ wherein nearly complete degradation of SDS was observed, and they are presented in Table 2. The $Q_{\text {eq }}$ value of free STB3 cells was higher than free STB4 cells at both 10 and $100 \mathrm{mg} \mathrm{L}^{-1} \mathrm{SDS}$, which was also observed in STB3 immobilized web samples. Furthermore, it was observed that $Q_{\text {eq }}$ values of both STB3 and STB4 immobilized webs increased with an increase in the initial SDS concentration, but more notable increases in $Q_{\text {eq }}$ values occurred in STB3 immobilized webs and the percentage degradation of these webs was highly increased $(96.5 \%$ for STB3/nCA and $98.8 \%$ for STB3/pCA) and reached or surpassed the percentage degradation levels of STB4 immobilized webs at $100 \mathrm{mg} \mathrm{L} \mathrm{L}^{-1}$ of initial SDS. This result may support our previous statement that STB3 cells have a higher SDS biodegradation capability than STB4 cells at higher concentrations.
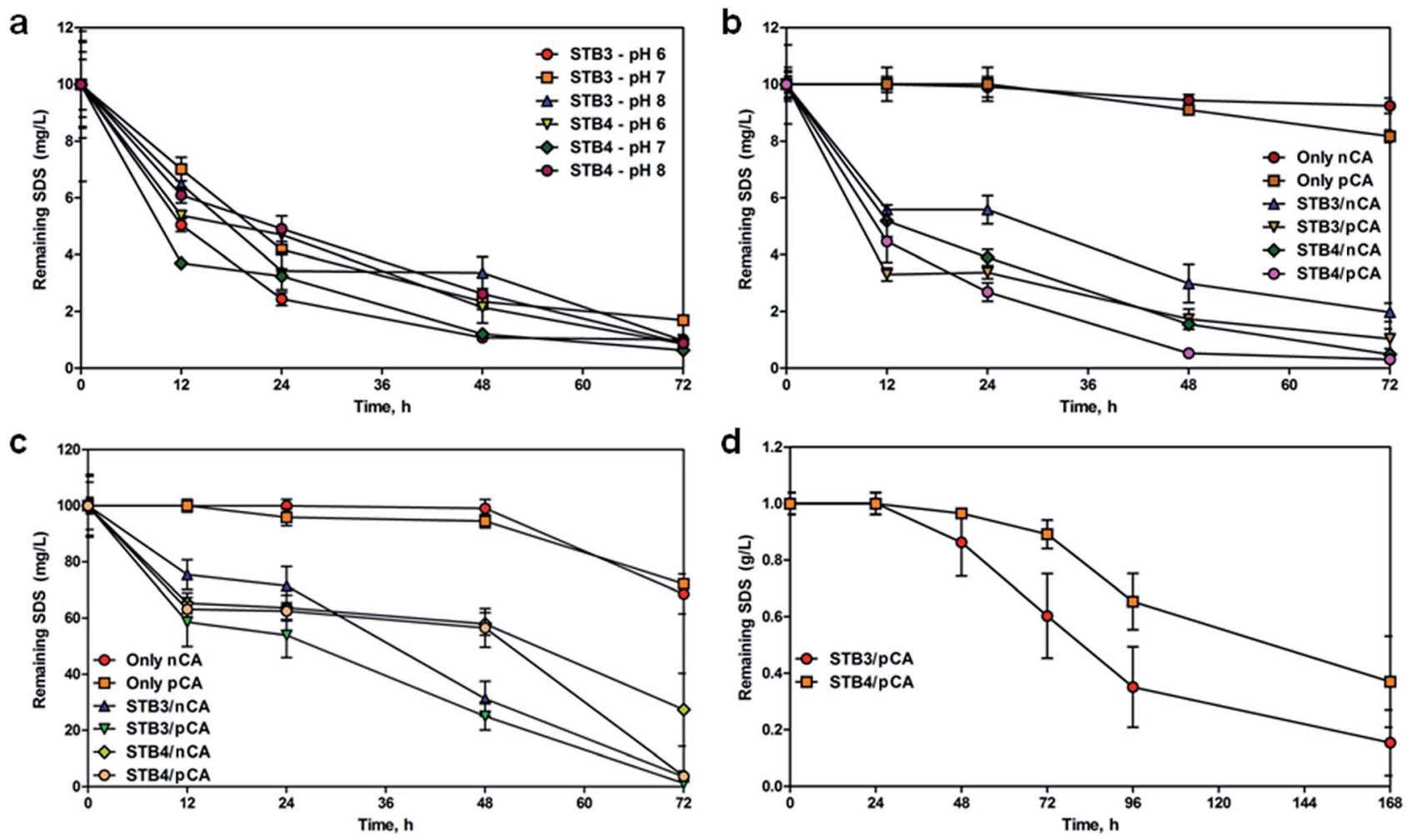

Fig. 4 SDS biodegradation profiles of (a) STB3 and STB4 strains for differential pH levels at $10 \mathrm{mg} \mathrm{L}^{-1}$ SDS, (b) pristine nCA, pristine pCA, STB3/ nCA, STB3/pCA, STB4/nCA and STB4/pCA webs at $10 \mathrm{mg} \mathrm{L}^{-1}$ SDS, (c) pristine nCA, pristine pCA, STB3/nCA, STB3/pCA, STB4/nCA and STB4/pCA webs at $100 \mathrm{mg} \mathrm{L}^{-1}$ SDS and (d) STB3/pCA and STB4/pCA webs at $1 \mathrm{~g} \mathrm{~L}^{-1} \mathrm{SDS}$. Error bars represent the mean of three independent replicates. 
Table 2 Degradation capacities of free STB3 and STB4 cells, and STB3/nCA, STB3/pCA, STB4/nCA, STB4/pCA webs at equilibrium at the end of the degradation period. $T=30^{\circ} \mathrm{C}$, agitation rate: $180 \mathrm{rpm}$

\begin{tabular}{|c|c|c|c|c|}
\hline Sample name & $\begin{array}{l}\text { Initial concentration } \\
\left(C_{0}\right)\end{array}$ & Removed SDS amount & $Q_{\text {eq }}\left(\mathrm{mg} \mathrm{g}^{-1}\right)$ & Removal (\%) \\
\hline STB3 only & $10 \mathrm{mg} \mathrm{L}^{-1}$ & $8.3 \mathrm{mg} \mathrm{L}^{-1}$ & $29.66 \pm 0.54$ & $83 \%$ \\
\hline STB4 only & $10 \mathrm{mg} \mathrm{L}^{-1}$ & $9.37 \mathrm{mg} \mathrm{L}^{-1}$ & $20.06 \pm 0.23$ & $93.7 \%$ \\
\hline STB3/nCA & $10 \mathrm{mg} \mathrm{L}^{-1}$ & $8.03 \mathrm{mg} \mathrm{L}^{-1}$ & $28.68 \pm 1.15$ & $80.3 \%$ \\
\hline STB3/pCA & $10 \mathrm{mg} \mathrm{L}^{-1}$ & $8.96 \mathrm{mg} \mathrm{L}^{-1}$ & $32.02 \pm 1.24$ & $89.6 \%$ \\
\hline STB $4 /$ nCA & $10 \mathrm{mg} \mathrm{L}^{-1}$ & $9.52 \mathrm{mg} \mathrm{L}^{-1}$ & $20.38 \pm 0.29$ & $95.2 \%$ \\
\hline STB4/pCA & $10 \mathrm{mg} \mathrm{L}^{-1}$ & $9.7 \mathrm{mg} \mathrm{L}^{-1}$ & $20.76 \pm 0.02$ & $97 \%$ \\
\hline STB3 only & $100 \mathrm{mg} \mathrm{L}^{-1}$ & $95 \mathrm{mg} \mathrm{L}^{-1}$ & $339.46 \pm 1.53$ & $95 \%$ \\
\hline STB4 only & $100 \mathrm{mg} \mathrm{L}^{-1}$ & $66.8 \mathrm{mg} \mathrm{L}^{-1}$ & $142.97 \pm 27.7$ & $66.8 \%$ \\
\hline STB3/nCA & $100 \mathrm{mg} \mathrm{L}^{-1}$ & $96.5 \mathrm{mg} \mathrm{L}^{-1}$ & $344.63 \pm 6.3$ & $96.5 \%$ \\
\hline STB3/pCA & $100 \mathrm{mg} \mathrm{L}^{-1}$ & $98.8 \mathrm{mg} \mathrm{L}^{-1}$ & $352.88 \pm 1.7$ & $98.8 \%$ \\
\hline STB $4 /$ nCA & $100 \mathrm{mg} \mathrm{L}^{-1}$ & $72.4 \mathrm{mg} \mathrm{L}^{-1}$ & $155.55 \pm 27.8$ & $72.4 \%$ \\
\hline STB $4 / p C A$ & $100 \mathrm{mg} \mathrm{L}^{-1}$ & $96.28 \mathrm{mg} \mathrm{L}^{-1}$ & $206.16 \pm 3.98$ & $96.28 \%$ \\
\hline STB3/pCA & $1 \mathrm{~g} \mathrm{~L}^{-1}$ & $846.47 \mathrm{mg} \mathrm{L}^{-1}$ & $3023.01 \pm 413.5$ & $84.66 \%$ \\
\hline STB4/pCA & $1 \mathrm{~g} \mathrm{~L}^{-1}$ & $630.61 \mathrm{mg} \mathrm{L}^{-1}$ & $1350.34 \pm 345.9$ & $63.01 \%$ \\
\hline
\end{tabular}

\subsection{Adsorption isotherms and order of reactions}

The estimated values of adsorption coefficients for three isotherm models (Langmuir, Freundlich and Toth) are listed in Table S1. $\dagger$ All of the tested models in two different samples have shown good fitting properties. For the STB3/pCA sample, Langmuir and Toth isotherms have shown slightly better correlation with the $R y^{2}$ value of 0.992 , while this value is 1.000 for the STB4/pCA sample in all three models. Since the Langmuir model is not the single best fitting model in both samples, the SDS removal process is not likely to be monolayer in nature, rather it is of heterogeneous and multilayer nature by bacteria immobilized web samples. ${ }^{33}$ The maximum removal capacities $\left(Q_{\max }\right)$ of web samples were estimated to be $3367 \mathrm{mg} \mathrm{g}^{-1}$ for STB3/pCA and $1464 \mathrm{mg} \mathrm{g}^{-1}$ for STB4/pCA under the Langmuir model, while they were $3023 \mathrm{mg} \mathrm{g}^{-1}$ for STB3/pCA and $1350 \mathrm{mg}$ $\mathrm{g}^{-1}$ for STB4/pCA under the Toth model, implying STB3/pCA has a much higher removal capacity for SDS.

The $R^{2}$ values of different order plots for STB3/pCA and STB4/pCA are listed in Table S2. $\dagger$ STB3/pCA and STB4/pCA samples show the highest correlation for the zero order model with $R^{2}$ values of 0.9319 and 0.8531 , respectively; suggesting the SDS removal process by both web samples is an enzymecatalyzed degradation, as enzyme-catalyzed reactions often fall under the zero order model. ${ }^{34}$ Since the total surface area has an essential role in the zero order model, the higher SDS removal capacities of bacteria/pCA samples can also be attributed to the higher surface area of the immobilized bacteria, in contrast to the bacteria/nCA samples where higher bacterial immobilization might lead to aggregation and decrease in the total surface area.

\subsection{LC-MS analysis}

LC-MS analysis was performed to monitor the remaining SDS and its byproducts in the bacterial growth media after the incubation process. Biodegradation of SDS has been studied previously and the known byproducts of SDS before proceeding to the fatty acid metabolism are 1-dodecanol, dodecanal and laurate.$^{35}$ According to the LC-MS analysis results, SDS (molar mass: $\sim 288 \mathrm{~g} \mathrm{~mol}^{-1}$ ) was observed at around $265 \mathrm{~m} / \mathrm{z}$ by releasing sodium ions (Fig. S3 $\uparrow$ ), and nutrient broth gave various peaks in the range of $100-180 \mathrm{~m} / \mathrm{z}$. For post-incubation samples, no explicit peaks at around 184, 186 and $199 \mathrm{~m} / \mathrm{z}$ were observed, corresponding to the molar masses of dodecanal, 1dodecanol and laurate, respectively. It was concluded that, while the remaining SDS in media can be monitored by LC-MS analysis, the byproducts cannot be seen since these metabolites have a very short lifetime and they are quickly processed for further fatty acid metabolism. The counts (\%) ratio for the remaining SDS at around $265 \mathrm{~m} / \mathrm{z}$ was higher for the STB4 sample, revealing lower SDS degradation had occurred for this sample, which was also observed in the SDS biodegradation experiments of free STB4 cells (Table 2).

\subsection{Reusability and applicability of STB3/pCA and STB4/ pCA biocomposites}

After the end of the biodegradation experiments, the same web samples were tested for reusability in five consecutive cycles. Although significant portions of SDS were degraded by STB3/ pCA and STB4/pCA webs at $1 \mathrm{~g} \mathrm{~L}^{-1}, 100 \mathrm{mg} \mathrm{L}^{-1}$ was selected as the initial concentration for the reusability test rather than 1 $\mathrm{g} \mathrm{L}^{-1}$, since complete degradation could not be achieved and the degradation time highly increased at $1 \mathrm{~g} \mathrm{~L}^{-1}$ of SDS. As seen in Fig. 5, while the SDS biodegradation capabilities of STB3/pCA and STB4/pCA webs were considerably low for the initial cycles, they recovered in the following cycles, especially for the STB3/ pCA web. This result might be related with losses of viable bacterial cells and metabolic activity for the biocomposite webs, after exposure to a very high concentration of SDS $\left(1 \mathrm{~g} \mathrm{~L}^{-1}\right)$ in the previous experiment. On the other hand, the degradation performances and viable cell counts started to recover at convenient conditions, during the test period at an initial SDS concentration of $100 \mathrm{mg} \mathrm{L}^{-1}$ where bacterial cells can rapidly grow and immobilize on the fibrous surfaces with a high metabolic activity, leading to higher bacterial attachment and 


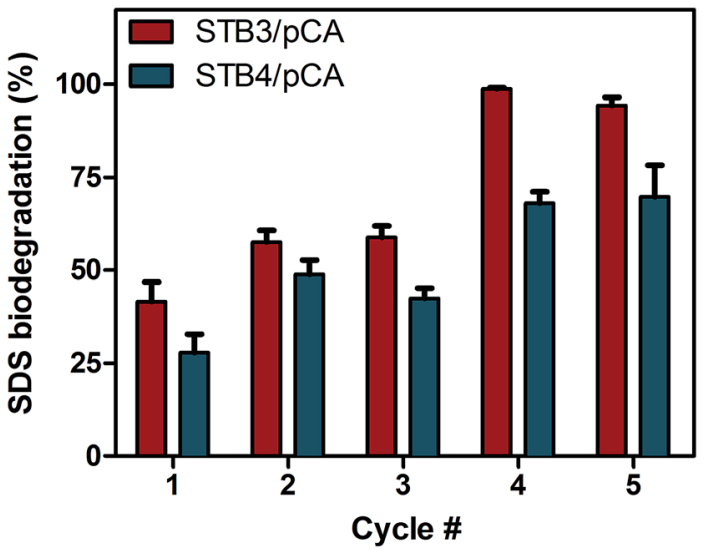

Fig. 5 Reusability test results of STB3/pCA and STB4/pCA webs for 5 cycles of SDS biodegradation at an initial concentration of $100 \mathrm{mg} \mathrm{L}^{-1}$. Error bars represent the mean of three independent replicates.

higher degradation efficiencies, and indeed at the end of the reusability test, higher numbers of viable cells were counted for both STB3/pCA and STB4/pCA web samples (Table 1). The test results indicated that STB3/pCA has a more efficient SDS biodegradation profile than STB4/pCA during the reusability test, and has a higher recovery capability for long term use at the tested concentration. Since the viable cell numbers increased for both samples (especially for STB3/pCA) during the reusability test, their removal capacities have altered and differed from the pre-reusability test conditions. It was inferred that, while $1 \mathrm{~g} \mathrm{~L}^{-1}$ of initial SDS might be toxic and constrain the metabolic activities of bacterial cells, $100 \mathrm{mg} \mathrm{L}^{-1}$ of initial SDS is appropriate for seeing the maximal biodegradation performances of the bacteria immobilized webs and for their repeated use. SEM imaging was applied on STB3/pCA and STB4/pCA webs to monitor the presence of immobilized bacteria at the end of the reusability test. As seen in Fig. S4, $\uparrow$ robust attachment of bacterial cells and biofilm-like structures on both web samples were observed, supporting the viable cell counting results of STB3/pCA and STB4/pCA after the reusability test (Table 1).

Remediation of anionic surfactants from water systems is a critical issue and greener approaches have received more attention. ${ }^{4,9,10,36,37}$ In addition, the use of biointegrated functional electrospun fibrous webs for the remediation of contaminated water systems has been explored in recent years and there are few examples in the literature for the applications of these kind of materials. For remediation of nitrate in aqueous systems, Eroglu et al. produced a novel biocomposite by immobilization of microalgal cells on electrospun chitosan nanofiber mats. ${ }^{\mathbf{1 1}}$ In recent studies performed by our group, specific bacterial or algal strains have been attached on electrospun fibrous webs for ammonium bioremoval, ${ }^{20}$ methylene blue dye biodegradation, ${ }^{21}$ reactive dye biodegradation ${ }^{22}$ and simultaneous removal of hexavalent chromium and a reactive dye. ${ }^{23}$ In the present study, we focused on anionic surfactant bioremediation and therefore produced novel biocomposite webs by immobilization of two different SDS degrading bacterial strains on electrospun nCA and pCA webs. It was observed that, bacterial cells strongly immobilized on nCA and pCA fibrous surfaces, the bacteria immobilized webs exhibited similar biodegradation performances with free STB3 and STB4 cells and can be reused for several cycles of SDS biodegradation with recovery capabilities. $1 \mathrm{~g} \mathrm{~L}^{-1}$ of SDS was found as potentially toxic for STB3 and STB4 cells since the degradation profiles of STB3/pCA and STB4/pCA highly decreased right after this experiment as seen in Fig. 5, still STB3/pCA and STB4/pCA webs were able to degrade significant portions of SDS at this concentration. The bacterial strains show efficient biodegradation profiles at different $\mathrm{pH}$ levels for the initial SDS concentration of $10 \mathrm{mg} \mathrm{L}^{-1}$, indicating the biodegradation performances of both strains were not significantly affected by pH differences within 6.0-8.0. Although highly efficient results could be achieved at different concentrations for SDS biodegradation, the bacteria immobilized webs are still improvable by increasing the number of attached bacteria or optimizing the bacterial growth conditions. Overall, these results are highly promising and with successful optimizations, STB3/pCA and STB4/pCA webs may be utilized continually for SDS biodegradation in aqueous environments.

\section{Conclusions}

Here, we present novel biocomposite webs that were obtained by immobilization of SDS degrading bacterial strains on electrospun cellulose acetate (CA) webs (non-porous (nCA) and porous (pCA) webs). The bacterial attachment has been evaluated regularly by bacterial cell counting (VCC assay) and SEM imaging, and the bacterial attachment was ended after 25 days based on these results. The results of biodegradation experiments revealed that SDS remediation capabilities of bacteria immobilized webs were mainly based on the bacterial existence and were highly similar to the unimmobilized bacterial cells. Since bacteria immobilized web samples were highly efficient for SDS remediation up to $100 \mathrm{mg} \mathrm{L}^{-1}$ of initial SDS, the two most effective webs (STB3/pCA and STB4/pCA) were therefore selected for testing their SDS remediation capability at a considerably high concentration $\left(1 \mathrm{~g} \mathrm{~L}^{-1}\right)$. Although significant portions of SDS were degraded by STB3/pCA and STB4/pCA in this experiment, $1 \mathrm{~g} \mathrm{~L}^{-1}$ of SDS was found as stringent for the metabolic activity and viability of bacterial cells, therefore the test concentration of the reusability test was adjusted at $100 \mathrm{mg}$ $\mathrm{L}^{-1}$. While the initial SDS biodegradation performances of STB3/pCA and STB4/pCA were considerably low in the reusability test (due to the harmful effects of the previous experiment on bacterial cells), they recovered in the next cycles and reached adequate levels especially for the STB3/pCA sample. It was concluded that, the bacteria immobilized webs are potentially reusable and improvable, suggesting they may be used repeatedly for SDS remediation in water systems.

\section{Acknowledgements}

The Scientific and Technological Research Council of Turkey (TUBITAK, project \#114Y264) is acknowledged for funding the 
research. Şişecam Group is acknowledged for their cooperation and support. Dr Uyar acknowledges The Turkish Academy of Sciences - Outstanding Young Scientists Award Program (TUBAGEBIP) for partial funding of the research. A. Celebioglu acknowledges TUBITAK project \#113Y348 for a postdoctoral fellowship. O. F. Sarioglu acknowledges TUBITAK BIDEB (2211C) for National Ph.D. Scholarship. The authors thank to Dr N. Oya San Keskin for technical assistance and guidance for conducting the biodegradation experiments.

\section{References}

1 R. A. Goodnow and A. P. Harrison Jr, Appl. Microbiol., 1972, 24, 555-560.

2 US EPA, Fate and Transport of Nonionic Surfactants, United States Environmental Protection Agency, Washington, DC, 1999-2001.

3 R. L. Crawford and D. L. Crawford, Bioremediation: Principles and Applications, Cambridge University Press, Cambridge, 1996.

4 A. Dhouib, N. Hamad, I. Hassairi and S. Sayadi, Process Biochem., 2003, 38, 1245-1250.

5 S. Otta, B. Swain, R. Panigrahy, K. Panda and N. K. Debata, JMM Case Rep., 2014, 1, e001065.

6 C. M. Ghevariya, J. K. Bhatt and B. P. Dave, Bioresour. Technol., 2011, 102, 9668-9674.

7 F. Grimont and P. A. D. Grimont, in The Prokaryotes, ed. M. Dwarkin, S. Falkow, E. Rosenberg, K. H. Schleifer and E. Stackebrandt, Springer, New York, 3rd edn, 2006, vol. 6, ch. 3.3.11, pp. 219-244.

8 C. R. Mahon, D. C. Lehman and G. Manuselis, in Textbook of Diagnostic Microbiology, Elsevier, Amsterdam, 5th edn, 2015, ch. 19, pp. 420-454.

9 K. M. Khleifat, Curr. Microbiol., 2006, 53, 444-448.

10 K. M. Khleifat, Enzyme Microb. Technol., 2006, 39, 1030-1035.

11 E. Eroglu, V. Agarwal, M. Bradshaw, X. Chen, S. M. Smith, C. L. Raston and K. S. Iyera, Green Chem., 2012, 14, 26822685.

12 L. Hall-Stoodley, J. W. Costerton and P. Stoodley, Nat. Rev. Microbiol., 2004, 2, 95-108.

13 S. Ramakrishna, K. Fujihara, W. Teo, T. Lim and Z. Ma, An Introduction to Electrospinning and Nanofibers, World Scientific Publishing Company, Singapore, 2005.

14 J. H. Wendorff, S. Agarwal and A. Greiner, Electrospinning: Materials, Processing, and Applications, Wiley-VCH Verlag GmbH \& Co. KGaA, Weinheim, 2012.

15 A. Greiner and J. Wendorff, Angew. Chem., Int. Ed., 2007, 46, 5670-5703.
16 S. Ramakrishna, K. Fujihara, W. E. Teo, T. Yong, Z. Ma and R. Ramaseshan, Mater. Today, 2006, 9, 40-50.

17 K. Yoon, B. Hsiao and B. Chu, J. Mater. Chem., 2008, 18, 5326-5334.

18 T. Uyar, R. Havelund, J. Hacaloglu, F. Besenbacher and P. Kingshott, ACS Nano, 2010, 4, 5121-5130.

19 Y. Liu, L. Gan, Z. Chen, M. Megharaj and R. Naidu, J. Hazard. Mater., 2012, 229-230, 419-425.

20 O. F. Sarioglu, O. Yasa, A. Celebioglu, T. Uyar and T. Tekinay, Green Chem., 2013, 15, 2566-2572.

21 N. O. San, A. Celebioglu, Y. Tumtas, T. Uyar and T. Tekinay, RSC Adv., 2014, 4, 32249.

22 N. O. San-Keskin, A. Celebioglu, T. Uyar and T. Tekinay, Ind. Eng. Chem. Res., 2015, 54, 5802-5809.

23 N. O. San-Keskin, A. Celebioglu, O. F. Sarioglu, A. D. Ozkan, T. Uyar and T. Tekinay, RSC Adv., 2015, 5, 86867-86874.

24 S. Klein, R. Avrahami, E. Zussman, M. Beliavski, S. Tarre and M. Green, J. Ind. Microbiol. Biotechnol., 2012, 39, 1605-1613. 25 A. Celebioglu and T. Uyar, Mater. Lett., 2011, 65, 2291-2294. 26 K. Hayashi, Anal. Biochem., 1975, 67, 503-506.

27 N. Rijpens, G. Vlaemynck, R. Rossau, L. Herman and G. Jannes, Lett. Appl. Microbiol., 1998, 27, 198e202.

28 H. Kobayashi, M. Oethinger, M. J. Tuohy, G. W. Procop and T. W. Bauer, Clin. Orthop. Relat. Res., 2009, 467, 1360-1364.

29 C. J. Buchko, L. C. Chen, Y. Shen and D. C. Martin, Polymer, 1999, 40, 7397-7407.

$30 \mathrm{H}$. Wagner, T. Siebert, D. J. Ellerby, R. L. Marsh and R. Blickhan, Biomech. Model. Mechanobiol., 2005, 4, 10-19.

31 D. Greif, D. Wesner, J. Regtmeier and D. Anselmetti, Ultramicroscopy, 2010, 110, 1290-1296.

32 L. C. Hsu, J. Fang, D. A. Borca-Tasciuc, R. W. Woroboa and C. I. Moraru, Appl. Environ. Microbiol., 2013, 79, 2703-2712.

33 Z. Ergul-Ulger, A. D. Ozkan, E. Tunca, S. Atasagun and T. Tekinay, Sep. Sci. Technol., 2014, 49, 907-914.

34 I. Tinoco, K. Sauer and J. C. Wang, Physical Chemistry Principles and Applications in Biological Sciences, Prentice Hall, 1996.

35 M. Walczak and W. Donderski, Pol. J. Environ. Stud., 2004, 13, 325-331.

36 M. M. Abboud, K. M. Khleifat, M. Batarseh, K. A. Tarawneh, A. Al-Mustafa and M. Al-Madadhah, Enzyme Microb. Technol., 2007, 41, 432-439.

37 M. Y. Shukor, W. S. W. Husin, M. F. A. Rahman, N. A. Shamaan and M. A. Syed, J. Environ. Biol., 2009, 30, 129-134. 